\title{
NITRIC OXIDE IN HEMODIALYSIS PATIENTS
}

Beti Dejanova ${ }^{1}$, Petar Dejanov ${ }^{2}$, Suncica Petrovska ${ }^{1}$, Vlada Jakovljevic ${ }^{3}$

${ }^{1}$ Institute of Physiology,

${ }^{2}$ Clinic of Nephrology, Medical Faculty Skopje, R. Macedonia,

${ }^{3}$ Institute of Physiology, Medical Faculty, Kragujevac, R. Serbia

\section{AZOT OKSID KOD PACIJENATA NA HEMODIJALIZI \\ Beti Dejanova ${ }^{1}$, Petar Dejanov' ${ }^{2}$, Suncica Petrovska ${ }^{1}$, Vlada Jakovljevic ${ }^{3}$ Institut za fiziologiju, \\ ${ }^{2}$ Klinika za nefrologiju, Medicinski fakultet Skopje, R. Makedonija, \\ ${ }^{3}$ Institut za fiziologiju, Medicinski fakultet, Kragujevac, R. Srbija}

Received / Primljen: 19. 05. 2011.

Accepted / Prihvaćen: 03. 06. 2011.

\section{ABSTRACT}

Nitric oxide (NO) is a molecule that has an important role in many physiological and pathological conditions, necessitating more studies to elucidate its function in various diseases. Patients with renal failure present impaired NO activity that may influence disease development and prognosis. The aim of the study was to measure NO in hemodialysis (HD) patients as related to HD duration and erythropoietin (rhEpo) therapy. The NO concentration was measured in 76 HD patients and 30 healthy control subjects. The patients were divided into three groups by the duration of HD: group $I,<5$ years $(n=26)$; group II, 5-10 years $(n=22)$; and group III $>10$ years $(n=28)$. The HD patients were divided into two groups based on the receipt of rhEpo therapy: group I without rhEpo therapy $(n=37)$ and group II with rhEpo therapy $(n=39)$. In an evaluation study of NO level after the $6^{\text {th }}$ month of rhEpo therapy, the HD patients were divided into 2 groups: group I without rhEpo therapy $(n=20)$ and group II with rhEpo therapy $(n=27)$. The NO level in $H D$ patients was measured at 0, 3 and 6 months. Routine haematological parameters were assayed along with NO. $H D$ patients presented an increased NO level compared to controls $(p<0.001)$. There were no statistical differences in NO levels observed among the HD duration groups. Patients receiving rhEPO supplementation therapy with rhEpo presented decreased NO levels $(p<0.01)$. In the evaluation study, $H D$ patients receiving rhEpo therapy again presented lower NO levels $(p<0.05)$.

These results indicate that the increased NO values observed in HD patients is are probably due to the induction of $H D$ membrane and/or a lack of renal excretion. Erythropoietin therapy decreased NO levels, which may improve patient condition and contribute to better disease outcome.

Key words: nitric oxide, hemodialysis, erythropoietin

\section{SAŽETAK}

Molekul azotnog monoksida (NO) ima važnu ulogu u mnogim fiziološkim $i$ patološkim stanjima na šta ukazuju mnoge studije koje objašnjavaju njegovu funkciju u različitim bolestima. Bubrežne bolesti pokazuju poremećaj aktivnosti NO koja utiče na razvoj bolesti i njenu prognozu. Cilj ove studije je da se kod pacijenata na hemodijalizi (HD) ispita povezanost NO-a sa dužinom trajanja hemodijalize $i$ sa eritropoetinskom terapijom (rhEpo). Koncentracija NO-a je odredena kod 76 pacijenata na HD $i$ kod 30 zdravih ispitanika kao kontrolne grupe. U odnosu na dužinu trajanja $H D$, pacijenti su podeljeni u tri grupe: I grupa $-<5$ godina ( $n=26) ;$ II grupa 5-10 godina $(n=22) ;$ i III grupa $>10$ godina $(n=28)$. U odnosu na rhEpo terapiju pacijenti na HD su podeljeni u dve grupe: I grupa - bez terapije ( $n=37)$;I grupa - sa rhEpo terapijom $(n=39)$. U evaluacijskoj studiji NO-a, $u$ toku šestomesečne terapije rhEpo-om, pacijenti na hemodijalizi su podeljeni u dve grupe: I grupa - bez rhEpo terapije $(n=20)$; II grupa - sa rhEpo terapijom $(n=27)$. Nivo NO-a kod pacijenata na HD je određivan posle 0, 3 i 6 meseci. Ispitani su rutinski hematološki parametri i NO. U odnosu na kontrolnu grupu, NO pokazuje porast kod pacijenata na HD ( $p<0.001)$. U odnosu na dužinu trajanja HD, NO ne pokazuje statističku razliku. Kod pacijenata na HD koji primaju suplementnu rhEpo terapiju, nivo NO-a opada ( $p<0.01)$. U evaluacijskoj studiji kod pacijenata na HD nivo NO-a opada u odnosu na rhEPo terapiju $(p<0.05)$.

$\mathrm{Na}$ osnovu rezultata možemo zaključiti da je porast NO-a kod pacijenata na HD uzrokovan hemodijaliznom membranom $i$ / ili nedostatkom renalne ekskrecije. Terapija rhEpo-om pokazuje pozitivne efekte preko smanjenja nivoa NO-a što može poboljšati stanje pacijenta $i$ doprinosi boljem ishodu bolesti.

Ključne reči: azot monoksid, hemodijaliza, eritropoetin.

\section{Abbreviations: \\ ESRD - end-stage renal disease HD - haemodialysis NO - nitric oxide \\ NOS - nitric oxide synthase \\ ONOO- - peroxynitrite \\ rhEpo - erythropoietin




\section{INTRODUCTION}

Underlying concentration changes in biological molecules in hemodialysis (HD) patients are common and may be useful indicators of disease state. In recent decades, there has been much interest focused on nitric oxide (NO) and its link to renal disease.

Nitric oxide (NO), known as "endothelium-derived relaxing factor", is produced from L-arginine, oxygen and NADPH by nitric oxide synthase (NOS) enzymes. It is an important messenger molecule involved in many pathological and physiological processes (1). Its physiological role is related to vessel homeostasis via the inhibition of vascular smooth muscle contraction and growth, inhibition of platelet aggregation, and inhibition of white blood cell adhesion to the endothelium (2). NO also plays a role in inflammation and immune responses when generated by the phagocytes during the process of killing bacteria (via DNA damage) (3). Therefore, $\mathrm{NO}$ is a crucial physiological messenger molecule that contributes to blood pressure regulation, blood clotting control, immune defence, sight, smell and likely the processes of learning and memory. However, $\mathrm{NO}$ also contributes to pathologic states such as hypertension, stroke, diabetes mellitus, renal disease, impotence and long-term depression. NO, a small molecule, is a free radical, which makes it very reactive with the metal centres of cell proteins and other reactive groups. $\mathrm{NO}$ overproduction may result in an oxidant effect with the superoxide anion $\mathrm{O}_{2}$ - producing a toxic molecule of peroxynitrite (ONOO-). Peroxynitrite contributes to vascular cell impairment, stroke and other neurological problems. Furthermore, a high NO level during severe bacterial infection can cause a blood pressure decrease resulting in septic shock and tissue damage. Prolonged exposure to a high NO level may lead to inflammation and malignant states including juvenile diabetes, multiple sclerosis, arthritis, colitis, chronic renal disease, carcinomas and other chronic diseases. NO also promotes tumour progression and metastasis due to angiogenesis, vessel maturation and dilatation $(4,5,6)$. As a reactive agent, $\mathrm{NO}$ has been reported to be involved in renal failure pathogenesis. Some authors have confirmed that chronic renal failure in rats might be caused by low NO levels. In contrast, increased NO concentration might cause platelet dysfunction followed by bleeding, which is common in uremic patients. NO production may correlate with the degree of chronic renal failure, and therefore, it may serve as an indicator of the disease state, including haematological parameters and creatinine clearance. According to Brunini et al., conflicting data are available on the systemic production of $\mathrm{NO}$ in chronic renal failure patients (7). As the haematological parameters in $\mathrm{HD} \mathrm{pa-}$ tients have been impaired, erythropoietin (rhEpo) therapy is very effective. In addition to its main role in controlling erythropoiesis, NO has other beneficial effects such as an anti-inflammatory effect, an anti-apoptotic effect, an anti-free radical formation effect and the ability to enhance the proliferation of smooth muscle cells (angiogenesis) $(8,9)$.

The aim of the study was to evaluate nitric oxide (NO) levels in patients with end- stage renal disease (ESRD), taking into account their HD duration period and rhEpo supplementation therapy.

\section{METHODS}

A group of $76 \mathrm{HD}$ patients was enrolled. Their haematological parameters (haemoglobin, haematocrit, red blood cell count and white blood cell count) and NO level were measured and compared with the control group values. The control group consisted of 30 sex- and age-matched healthy subjects. The HD patients were divided into 3 groups based on $\mathrm{HD}$ duration: group I, $<5$ years $(\mathrm{n}=26)$; group II, $5-10$ years $(\mathrm{n}=22)$; and group III, $>10$ years $(n=28)$. HD patients were also divided into two groups based on the receipt of rhEpo therapy: group I did not receive rhEpo therapy $(\mathrm{n}=37)$, and group II received rhEpo therapy ( $n=39)$. In an evaluation study of NO levels during the 6th month of rhEpo, HD patients were divided again into 2 groups: group I did not receive rhEpo therapy $(\mathrm{n}=20)$, and group II received rhEpo therapy $(\mathrm{n}=27)$. The NO level in HD patients was examined at 0,3 and 6 months. rhEpo doses (Eprex-Cilag-Janssen) were given subcutaneously following an HD session (20-25 U/kg weekly) to achieve 10-11 g/dl haemoglobin and 35\% haematocrit. All patients were treated with HD for 4 hours, 3 times per week, using bicarbonate $\mathrm{HD}$ and polysulphone $\mathrm{HD}$ membranes. Blood samples were taken from the cubital vein before each HD session.

Standard laboratory techniques were used to measure the haematological parameters of haemoglobin, haematocrit, red blood cell count and white blood cell count. A microplate assay kit was used (OXIS, Oregon, USA) was used to assay NO levels. This method is based on NO degradation converting nitrates to nitrites by the enzymatic reduction with nitrate reductase using the Griess reagent.

Student's t test was used for statistical analysis with a significance level of 0.05 .

\section{RE SULTS}

The haematology test values in the HD patients were significantly different from the values in the control group, with a lower haemoglobin $(\mathrm{p}<0.05)$, lower haematocrit $(\mathrm{p}<0.01)$ and lower red blood cell count $(\mathrm{p}<0.05)$. There was no significance difference found in white blood cell count. An increased NO value was observed in HD patients compared to controls $(\mathrm{p}<0.001)$ (Table 1).

\begin{tabular}{|l|c|c|c|}
\hline & $\begin{array}{c}\text { Control group } \\
\mathbf{n}=\mathbf{3 0}\end{array}$ & $\begin{array}{c}\text { HD patients } \\
\mathbf{n}=\mathbf{4 5}\end{array}$ & $\mathbf{P}$ \\
\hline $\begin{array}{l}\text { Haemoglobin } \\
(\mathrm{g} / \mathrm{L})\end{array}$ & $121 \pm 19$ & $104 \pm 16$ & 0.05 \\
\hline Haematocrit & $0.42 \pm 0.14$ & $0.30 \pm 0.11$ & 0.01 \\
\hline $\begin{array}{l}\text { Red blood cells } \\
(\mathrm{X} 1012 / \mathrm{L})\end{array}$ & $4.41 \pm 1.0$ & $3.80 \pm 0.9$ & 0.05 \\
\hline $\begin{array}{l}\text { White blood } \\
\text { cells }(\mathrm{X} 109 / \mathrm{L}\end{array}$ & $6.90 \pm 1.8$ & $6.50 \pm 1.5$ & N.S. \\
\hline NO $(\mu \mathrm{mol} / \mathrm{L})$ & 57.419 & 150.238 & 0.001 \\
\hline
\end{tabular}

N.S., not statistical

Table 1. Haematological parameters and nitric oxide levels in HD patients 
No significant differences in NO levels were noted by HD duration: $<5$ years $(155.9 \pm 17 \mu \mathrm{mol} / \mathrm{L}) ; 5-10$ years $(168.6 \pm 31 \mu \mathrm{mol} / \mathrm{L})$; and $>10$ years $(166.7 \pm 47 \mu \mathrm{mol} / \mathrm{L})$, (Figure 1).

In HD patients receiving rhEpo supplementation therapy, a lower NO level was observed $(151.9 \pm 36 \mu \mathrm{mol} / \mathrm{L})$ when compared with the HD patients not receiving rhEpo therapy $(174.6 \pm 40 \mu \mathrm{mol} / \mathrm{L})(\mathrm{p}<0.01)$ (Figure 2).

In a 6-month evaluation study, NO level decreased if a HD patient was receiving rhEpo supplementation therapy. There was a decrease from $146 \pm 35 \mu \mathrm{mol} / \mathrm{L}$ to $130 \pm 37$ $\mu \mathrm{mol} / \mathrm{L}$ at the $3^{\text {rd }}$ month and from $122 \pm 34 \mu \mathrm{mol} / \mathrm{L}$ by the $6^{\text {th }}$ month $(\mathrm{p}<0.05)$. No significant difference in NO level was noted in the control group (Figure 3).

\section{DISCUSSION}

In renal physiology, NO plays important roles in processes such as glomerular haemodynamics, the tubuloglomerular negative feedback mechanism and renin release. Furthermore, physiological interactions between NO, renin-angiotensin II and superoxide anions provide a coordinated regulation of kidney function. The imbalance of these interactions may be linked to renal pathophysiology $(10,11)$. Uremic plasma induces endothelial NO synthesis, which leads to platelet dysfunction and other uremic manifestations. Several studies in experimental animals and humans have demonstrated an accumulation of NO metabolites during uraemia. Interestingly, uremic plasma can provoke NO production in endothelial cells. This enhancement in NO production may be related to the type of HD membrane used and seems to be more pronounced in patients who present with hypotension during $\mathrm{HD}$, which is also common for extracorporeal circulation $(7,12)$. Therefore, HD per se may stimulate NO production via inducible NOS (nitric oxide synthesise) as a part of the inflammatory response. However, there are differences between the biocompatibility of HD membranes regarding NO induction. The activity of endothelial NOS can be enhanced during HD sessions via the interaction of lymphomonocytes with the membranes, possibly mediated by TNF-alpha and IL-1 beta production (13). According to our results, NO levels were higher in HD patients than controls. This finding correlates with the results of other studies where the observed baseline NO generation was higher. The chronic hypotensive state in HD patients is associated with longer HD times and higher nitrate/nitrite plasma levels, suggesting enhanced NO production (14). In contrast, in 2000, Schmidt et al. suggested that the cause of higher NO levels in HD patients is a lack of renal excretion. In this study, no increased NO production in HD patients was recorded. Therefore, they suggest that NO production is low in these patients and may contribute to hypertension and disease progression. They support their opinion by presenting NO decreases after HD sessions (15, 16). These previous results may explain why, in the present study, the HD patient NO levels did not show any significant

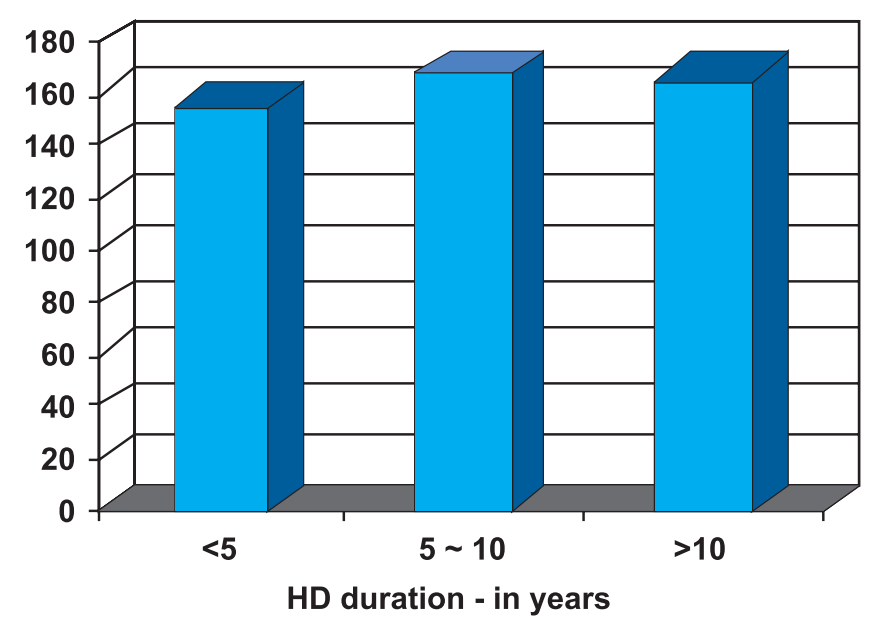

Figure 1. NO levels in the patients based on differing HD duration

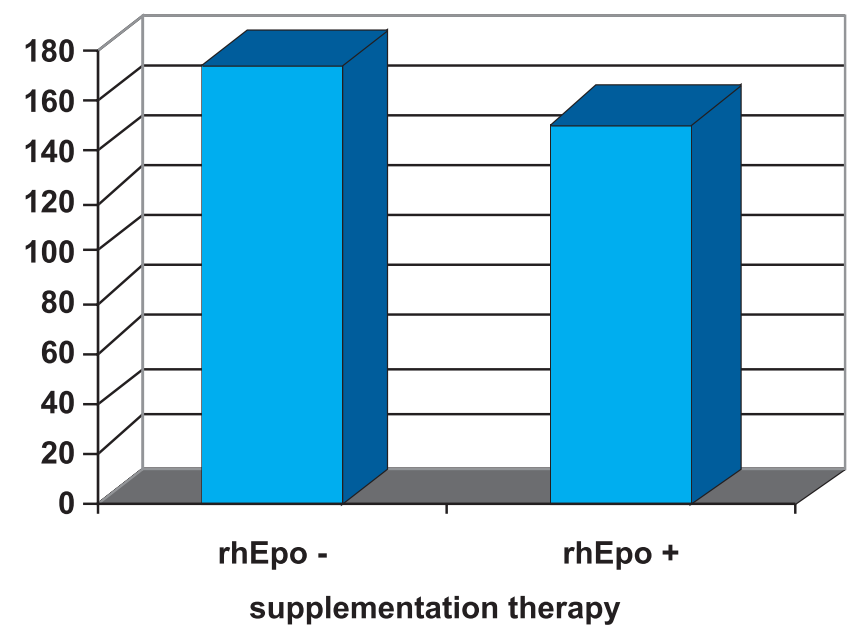

Figure 2. NO levels in HD patients undergoing rhEpo supplementation therapy

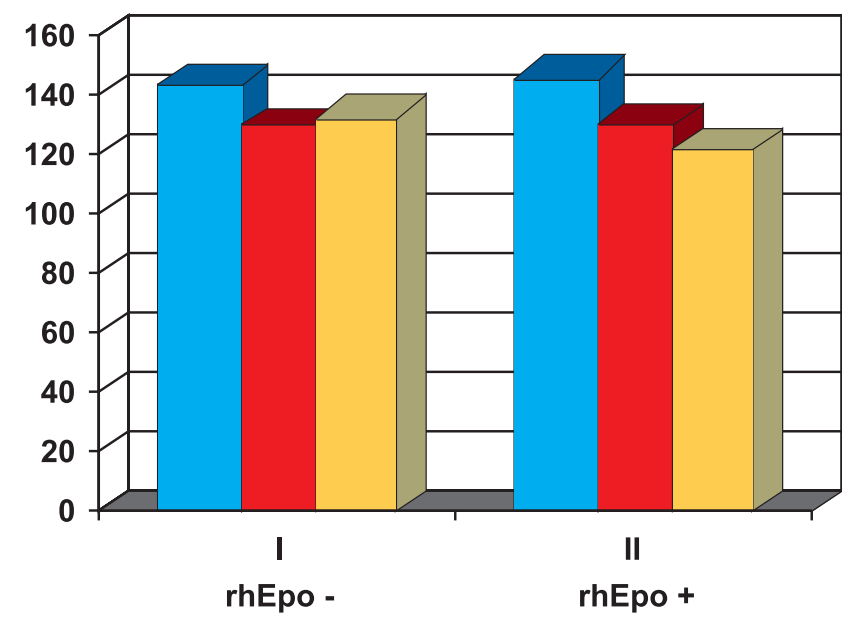

Figure 3. Evaluation of NO levels in HD patients after

3 and 6 months of rhEpo supplementation therapy 
difference related to HD duration time. In HD patients receiving rhEpo therapy, a decrease in NO level was observed, in concordance with the results of other studies. The role of rhEpo in decreasing NO level in HD patients may diminish the prooxidative effects of $\mathrm{NO}$ and the accompanying toxic influence. Therefore, rhEpo augments urinary nitrate/nitrite concentrations (17). According to a 2006 study by Desai et al., a 24 hour incubation of human aortic endothelial cells with rhEpo results in a downregulation of endothelial NOS protein expression. Thus, rhEpo significantly reduces NO production by both quiescent and proliferating endothelial cells (18). However, some studies indicate that prolonged rhEpo supplementation therapy may cause adverse effects due to its effect on NO. Nevertheless, Krapf et al. suggest that rhEpo may provoke arterial hypertension in HD patients. The vasoconstrictive effects of $\mathrm{NO}$ might be caused by both decreased systemic NO production and resistance to $\mathrm{NO}$ vasodilatation (19).

\section{CONCLUSION}

Based on the results of the present study, we conclude that $\mathrm{NO}$ values are increased in HD patients due to HD membrane induction as a part of the inflammatory response and/or a lack of renal excretion. Erythropoietin therapy, though it demonstrated the adverse effect of causing vasoconstriction, also demonstrated a beneficial effect by decreasing $\mathrm{NO}$ levels and preventing its prooxidative effect in combination with the superoxide anion. Such prevention may improve disease conditions and contribute to better disease outcomes.

\section{REFERENCES}

1. Martin W. Nitroxyl anion - the universal signaling partner of endogenously produced nitric oxide? Br J Pharmacol 2009; 157(4): 537-9.

2. Roberts W, Riba R, Homer-Vanniasinkam S, Farndale RW, Naseem KM. Nitric oxide specifically inhibits integrin-mediated platelet adhesion and spreading on collagen. Journal of Thrombosis and Haemostasis 2008; 6: 2175-85. doi: 10.1111/j.1538-7836.2008.03190.x

3. Tripathi P. Nitric oxide and immune response. Indian J Biochem Biophys 2007; 44(5): 310-9.

4. Fukumura D, Kashiwagi S, Jain RK. The role of nitric oxide in tumour progression. Nature Reviews Cancer 2006; 6: 521-34.

5. Cosentino F, Francia P, Musumeci B at al. Nitrix oxide release is impaired in hypertensive individuals with familial history of stroke. Am J Hypertens 2006; 19: 1213-6.
6. Pacher P, Beckman JS, Liaudet L. Nitric oxide and peroxynitrite in health and disease. Physiological reviews 2007; 87: 315-424.

7. Brunini TMC, Mendes Ribeiro AC, Ellory JC, Mann GE. Platelet nitric oxide synthesis in uremia and malnutrition: a role for L-arginine supplementation in vascular protection? Cardiovasc Res 2007;73(2):359-67.

8. Calo LA, Davis PA, Piccoli A, Pessina AC. A role for heme oxygenase- 1 antioxidant and antiapoptotic effects of erythropoietin: the start of a good news/bad new story? Nephron physiology 2006; 103:103-107.

9. Muller-Ehmsen J, Schmidt A, Krausgrill B, Schwinger RHG, Bloch W. Role of erythropoietin for angiogenesis and vasculogenesis: from embryonic development through adulthood. AJP-Heart 2006; 290(1):331-40.

10. Patzak A, Persson EA. Angiotensin II - nitric oxide interaction in the kidney. Current opinion in nephrology and hypertension 2007; 16 (1):46-51.

11. Kopkan L, Cervenka L. Renal interaction of renin-angiotensin system, nitric oxide and superoxide anion: implications in the pathophysiology of salt-sensitivity and hypertension. Physiol Res 2009; 58 (2): 55-67.

12. Fischer UM, Schindler R, Brixius K, Mehlorn U, Bloch W. Extracorporeal circulation activates endothelial nitric oxide sythase in erytrocytes. Ann Thorac Surg 2007; 84(6):2000-3.

13. Amore A, Bonaudo R, Ghigo D, at al. Enhanced production of nitric oxide by blood - dialysis membrane interaction. JAm Soc Nephrol 1995; 6:1278-83.

14. Coll E, Larrousse M, de la Sierra A, Collado S, Jimenez W, Cases A. Chronic hypotension in hemodialysis patients: role of functional vascular changes and vasodilator agents. Clin Nephrol 2008; 69(2):114-20.

15. Schmidt R, Baylis C. Total nitric oxide production is low in patients with chronic renal disease. Clin Nephrol 2000; 58:1261-66.

16. Bhogade RB, Suryakar AN, Katkam RV. Effect of antioxidant therapy on oxidative stress with special reference to hemodialysis. Biomed Res 2009; 20(2): 105-108.

17. Desai A, Zhao Y, Warren JS. Human recombinant erythropoietin augments serum asymmetric dimethylarginine concentration but does not compromise nitric oxide generation in mice. Nephrol Dial Transplant 2008; 23(5):1513-20.

18. Desai A, Zhao Y, Lankford HA, Warren JS. Nitric oxide suppresses EPO-induced monocyte chemoattractant protein-1 in endothelial cells: implications for atherogenesis in chronic renal disease. Laboratory Investigation 2006; 86: 369-79.

19. Krapf R, Hulter HN. Arterial hypertension induced by erythropoietin and erythropoiesis-stimulating agents. Clin J Am Soc Nephrol 2009; 4: 470-80. 